DOI: $10.30519 /$ ahtr.894577

Advances in Hospitality and Tourism Research (AHTR)

\title{
CULTURAL DESTINATION ATTRIBUTES, OVERALL TOURIST SATISFACTION AND TOURIST LOYALTY: FIRST TIMERS VERSUS REPEATERS
}

\author{
Ozan ATSIZ ${ }^{1}$ \\ Department of Tourism Management, Yozgat Bozok University, Turkey \\ ORCID: 0000-0003-2962-1903 \\ Orhan AKOVA \\ Department of Tourism Management, Istanbul University, Turkey \\ ORCID: 0000-0001-7740-2938
}

\begin{abstract}
This paper analyses the effects of the cultural attributes of tourist destinations on the satisfaction levels of visitors and the impact of this satisfaction rating on visitor loyalty. Additionally, a multiplegroup analysis was conducted to compare the responses of firsttime visitors and repeat visitors. For this study, a self-administered questionnaire was used to survey 411 international tourists who were visiting Istanbul, Turkey, through convenience sampling. The findings indicated that cultural attractions at the destination impacted the overall satisfaction rating of the visitors, and that this specific satisfaction rating determined the loyalty of the tourist to return to the destination. This relationship between cultural attractions, satisfaction and visitor loyalty was a significant factor for both groups.
\end{abstract}

\section{Article History}

Received 10 March 2021

Revised 14 August 2021

Accepted 16 August 2021

Published online 29 Sep. 2021

Keywords

cultural destination attributes tourist satisfaction tourist loyalty first-timers repeaters

\section{INTRODUCTION}

A cultural tourism destination is considered as a place with a variety of cultural attractions that meet the requirements of visitors (Atsiz et al., 2020) and, ultimately, impact their overall satisfaction with the destination (Huh \& Uysal, 2004). While tourism is the focus of these destinations, their cultural attractions have a determining role in the overall satisfaction and loyalty of visitors to that destination (Huh et al., 2006). Therefore, the standard and performance of these venues have a vital function in ensuring

\footnotetext{
${ }^{1}$ Address correspondence to Ozan Atsız (Ph.D.), Faculty of Tourism, Tourism Management, Yozgat Bozok University, Azizli, Yozgat, Turkey. E-mail: ozan.atsiz@bozok.edu.tr
} 
tourist satisfaction and loyalty. An analysis of these key attributes is critical in providing a successful marketing and development strategy to attract tourists to a destination (Eusébio \& Vieira, 2013). Examining the impact of cultural attractions on visitor satisfaction is particularly important to ensure that the destination remains competitive, as positive feedback to these attributes will enhance the loyalty of tourists to return to the destination (Baloglu et al., 2004).

The literature highlights several studies on the effect that the facilities and features of a tourist destination have on visitor satisfaction and loyalty (Baloglu et al., 2004; Eusébio \& Vieira, 2013; Ozturk \& Gogtas, 2016). Moreover, the impact of destination attributes on tourist satisfaction was examined by some prior studies (Albayrak \& Caber, 2013; Alegre \& Garau, 2010; Biswas et al., 2020; Hui et al., 2007; Kozak, 2002; Kwanisai \& Vengesayi, 2016) or tourist loyalty (Vareiro et al., 2019). Moreover, these studies generally investigate the general features of a destination rather than on specific aspects such as culture or heritage. Although its cultural attractions are fundamentally important to a destination and motivate many interested tourists to visit (Akova \& Atsiz, 2019; Atsiz et al., 2020), inadequate holistic research has been conducted on the impact of these attractions on tourist satisfaction and loyalty. Additionally, this evaluation can offer different results as it depends on whether the tourist was a first timer or a repeat visitor (Moniz, 2012). A review of the literature failed to yield any research that compared the experiences of first time and repeat visitors in this regard.

Istanbul, the most populous city in Turkey with over 15 million inhabitants (Turkish Statistical Institute (TUIK), 2020), which attracted a similar number of tourists in 2019 (İstanbul Provincial Directorate of Culture and Tourism, 2020), was the selected destination for this research. The city has many cultural and historical attractions that were included in the UNESCO World Heritage List in 1985 (UNESCO, 2020). The cultural heritage areas that were registered are "Sultanahmet Archaeological Park", "Suleymaniye Conservation Area", "Zeyrek Conservation Area", and "Land Walls Conservation Area." Additionally, Istanbul has numerous tangible and intangible cultural assets (Gursoy et al., 2021). Despite its many attractions, Istanbul has failed to capitalise on tourism revenues from the worldwide cultural tourism market (Gezici \& Kerimoglu, 2010). With this tourism trend on the rise, many destinations are developing their cultural attractions to encourage potential visitors and to promote repeat visits (Altunel \& Erkut, 2015). To date, studies on the cultural attractions of Istanbul have not featured in the literature. This study, therefore, aims to 
fill the gap in the research by analysing the impact of cultural attributes on the overall satisfaction response of tourists and visitor loyalty. The research will employ PLS-SEM, which is partial least squares-structural equation modelling. Additionally, this study will compare this evaluation according to the frequency of visits by tourists (i.e. first time and repeat tourists) through multi-group analysis. This analysis, as a composite-based technique, is recommended and deemed to be more appropriate for PLSSEM research (Rasoolimanesh et al., 2017).

This study will make a considerable empirical contribution to the literature in terms of the impact of cultural characteristics of a destination on tourist satisfaction and loyalty. Additionally, it will add to the knowledge by revealing the differences in satisfaction and loyalty of first time and repeat visitors to a cultural destination, and by providing a comparison between the specified tourist groups in terms of frequency of visit. Thus, the literature on tourism also will benefit from a methodological contribution. In addition, the findings will be beneficial to planners in tourist destinations in creating policies for cultural tourism and for tourism scholars.

The study has been divided into several parts. The first part provides a theoretical appraisal of the cultural attributes of the destination, tourist satisfaction and loyalty, and the development of hypotheses. The research method and results will be presented in subsequent sections, followed by discussion and a detailed demonstration of the implications of the findings. Finally, the limitations of the research and suggestions for further studies will be provided.

\section{THEORETICAL BACKGROUND AND HYPOTHESES DEVELOPMENT}

\section{Cultural Destination Attributes}

Destinations, as "amalgams of tourism products, offering an integrated experience to consumers" (Buhalis, 2000, P.97), have various attributes (e.g. nature, history, local culture, hospitality, infrastructure, service quality, accessibility, attractions both cultural and natural) that encourage tourists and allow the destinations to differ from others by providing unique offerings (Moon \& Han, 2018; Sirakaya et al., 1996). Among others, attractions particularly based on culture and heritage have gained in popularity and importance in many destinations (Gursoy et al., 2021; Huh \& Uysal, 2004). 
This reflects the long-held high level of interest by tourists in these attractions and activities. Cultural tourism has been widely examined by tourism scholars in different settings since 1970 (McKercher, 2020). Much of the previous work focused on documenting the market size, examining cultural tourists, and the economic impacts of cultural assets on destinations (Richards, 2018). Additionally, lists of cultural and heritage characteristics of a destination have been identified and their impact on tourists and destinations have been investigated (Huh \& Uysal, 2004).

These attributes comprise many tangible and intangible cultural elements, services and other amenities that may attract tourists to a destination (Huh \& Uysal, 2004; Lew, 1987). They are pivotal attractions that enrich the experience of the tourist in the destination (Prentice, 1993), while Reisinger et al. (2009) stated that they are among the essential components that have rich potential in creating future tourism demand. These attractions have been operating in numerous guises, but no standardised mechanism exists in the literature for their evaluation. In the tourism literature, several researchers identified and grouped the main or general cultural attributes of a destination. For example, a study by Huh and Uysal (2004) identified four main cultural attributes in a destination. The first relates to cultural attractions that include "museums, galleries, culture villages, historic buildings, and monuments", while the second focuses on heritage attractions, such as "handcrafts, architecture, traditional scenery, and the arts". Apart from these attributes, general tourist attractions and maintenance factors are considered as major attributes of a cultural destination. The general tour attractions comprise elements such as "religious sites, souvenirs, theatres, theme parks, tour packages, food, shopping venues, and guides", while the maintenance factors can be defined as facilities that satisfy the needs of tourists in terms of accessibility, events, information, and accommodation. Kim et al. (2007) also identified four main cultural destination attributes, which included musical events, commercial activities, indigenous festivals, and fairs and activities for those seeking an educational or aesthetical experience. Leask (2010) determined that museums, galleries and heritage attractions are some of the most important cultural attributes. Ghosh and Sofique (2012) detected two main cultural heritage attributes of a destination that impact the overall satisfaction of tourists - civil attractions (organised trips, music and dance, festivals and events, theatres and drama) and heritage attractions (monuments and historic buildings and architecture). Kim (2014) highlighted the role of local culture, events and activities, and hospitality as 
some attributes of a cultural destination that would provide memorable experiences for visitors.

Although many studies have examined the attributes of cultural destination both separately and holistically, there is no clear consensus on which cultural attributes should feature in a destination (Jumanazarov et al., 2020). Some scholars have emphasised that these attributes could differ across destinations because the attractions are unique to that destination. However, a study by Huh and Uysal (2004) shows the most promise as it clarifies the main attributes for a cultural destination.

\section{Tourist Satisfaction}

Tourist satisfaction is measured by comparing their experience of the destination with their expectations (Pizam et al., 1978). According to Eusébio and Vieira (2013), tourist satisfaction involves an emotive response to experiences at the destination. Satisfied tourists show that their expectations of the destination have been fulfilled and their experience was as good as anticipated (Chon \& Olsen, 1991). Therefore, the aspirations or expectations of the tourist prior to the visit and their actual experience of the destination are major factors that affect the level of satisfaction for tourists (Biodun et al., 2013). Other findings also highlighted the mental and emotional responses of tourists to their experience at a destination (del Bosque \& San Martín, 2008).

Tourist satisfaction is regarded as an essential element for a destination, as it provides the advantage of distinguishing it from other locations, it boosts its reputation, and determines the repeat selection of a destination by the visitor who has appreciated the services and attributes provided by the destination (Eusébio \& Vieira, 2013). An evaluation of the overall satisfaction levels of tourists would be beneficial to those working in hospitality and tourism, so that they may meet the needs of visitors, determine the main advantages and disadvantages of the venue, and identify issues that are crucial for providing a successful experience for the tourist (Meng et al., 2008). It has been widely recognised that the cultural attributes of a destination greatly enhance the overall satisfaction and distinctive experience of a destination for visitors.

\section{Tourist loyalty}

Many studies have acknowledged the significance of loyalty in the marketing of tourism and destinations (Gursoy et al., 2014; Suhartanto et 
al., 2020). Tourist loyalty has been shown to be a key factor in creating and maintaining the social and economic development of a region. This concept has been highly researched in the tourism sphere, and while previous research focused on the general attractions of a destination, limited attention has been paid to the cultural aspects. Research on loyalty mainly utilises two approaches - behavioural and attitudinal loyalty (Zhang et al., 2014).

Behavioural loyalty is measured by the frequency of visits to a business, attraction, or destination, and provides a genuine portrayal of how the performance of an attribute compares with others (Suhartanto et al., 2020). However, behavioural measurements of loyalty have been criticised for their lack of hypothetical analysis and their constricted appraisal of the multifaceted and energetic behaviour of tourists (Suhartanto, 2018). In addition, evaluating loyalty with this approach can hinder the measurement of real loyalty (Gursoy et al., 2014). Therefore, behavioural loyalty is not a helpful method for examining tourist loyalty to cultural attributes of destinations. Another method for examining loyalty (i.e. loyalty intention or conative loyalty) is through attitudinal methods (Almeida-Santana \& Moreno-Gil, 2018). This refers to the dedication of visitors to buy goods or services (Cong, 2016), to recommend destinations that they have visited, and to buying the same product or service even if its price has increased (Yoon \& Uysal, 2005). This is the conative element of the attitudinal method (Ajzen, 2005). Attitudinal loyalty should be anticipated as it is constructed on the tourist revisiting a destination with the intent to promote and support the attractions and the hospitality in the location (Suhartanto et al., 2020). Anticipating this type of behaviour is critical for the tourism sector (Reichheld, 2003). Therefore, it is appropriate for this research to use attitudinal loyalty when theorising and measuring loyalty towards attributes of cultural tourism.

\section{Relationships between variables and hypothesis}

According to Babolian Hendijani (2016), it is crucial to investigate the determinants of tourist satisfaction for a destination to derive a long-term competitive advantage. Tourist satisfaction has been broadly studied in the hospitality and tourism arena. Various scholars have attempted to assess the determinants of satisfaction and its effect on the behavioural intentions of tourists. The studies show that numerous factors determine satisfaction with a destination, such as the quality of service, the tourist experience, the perceived value, destination image, socio-demographic characteristics, and the attributes of the destination (Cetin, 2020; Chen \& Myagmarsuren, 2010; 
McDowall, 2010). Additionally, there is limited value in investigating the influence of these attributes on the overall satisfaction levels of visitors to different tourist settings (Johann \& Ghose, 2018; Kozak, 2002; Ozturk \& Gogtas, 2016). To get a better knowledge about the tourist evaluation towards cultural/heritage attributes and tourist satisfaction on these attributes has a pivotal role for destination managers, planners, and marketers in terms of destination positioning and promoting (Chi \& Qu, 2008; Yoon \& Uysal, 2005). Many scholars have demonstrated that the general attributes of a destination impact and determine overall tourist satisfaction (Alegre \& Garau, 2010; Biswas et al., 2020; Eusébio \& Vieira, 2013; Johann \& Ghose, 2018; Kozak, 2002). In addition, Ghosh and Sofique (2012) emphasise that heritage attractions have a key role in creating tourist satisfaction. Huh and Uysal (2004) also state that the cultural and heritage attributes of a destination influence tourist satisfaction. Therefore, the forthcoming hypotheses were formulated:

Hypothesis 1: General tour attractions affect overall tourist satisfaction.

Hypothesis 2: Heritage attractions of destination affect overall tourist satisfaction.

Hypothesis 3: Maintenance factors of destination affect overall tourist satisfaction.

Hypothesis 4: Cultural attractions of destination affect overall tourist satisfaction.

The link between tourist satisfaction and loyalty has been widely studied (Eusébio \& Vieira, 2013; Gursoy et al., 2014; Lee et al., 2011; McDowall, 2010; Suhartanto et al., 2020). The research emphasises that understanding the satisfaction level of tourists can be helpful in creating tourist loyalty to the destination. Additionally, these studies concluded that tourist satisfaction determines loyalty. Thus, the next hypothesis was formulated:

Hypothesis 5: Tourist satisfaction influences tourist loyalty.

This study also examines these variables according to the frequency of visits by tourists, both as repeat and first timer visitors, by employing a multi-group analysis. In the extant literature, this comparison is generally conducted on the image of the destination or the experience of the tourist (Schofield et al., 2020). Chi (2012) conducted a study on first-time and repeat visitors to examine loyalty to and satisfaction with a destination. According to this research, tourist satisfaction is key to creating loyalty to a destination among first-time visitors. The use of multi-group analysis to determine satisfaction with the attributes of cultural destinations and the loyalty of 
tourists measured by the frequency of their visits is not evident in the existing literature.

We sum up the set of hypotheses to be examined in Figure 1.

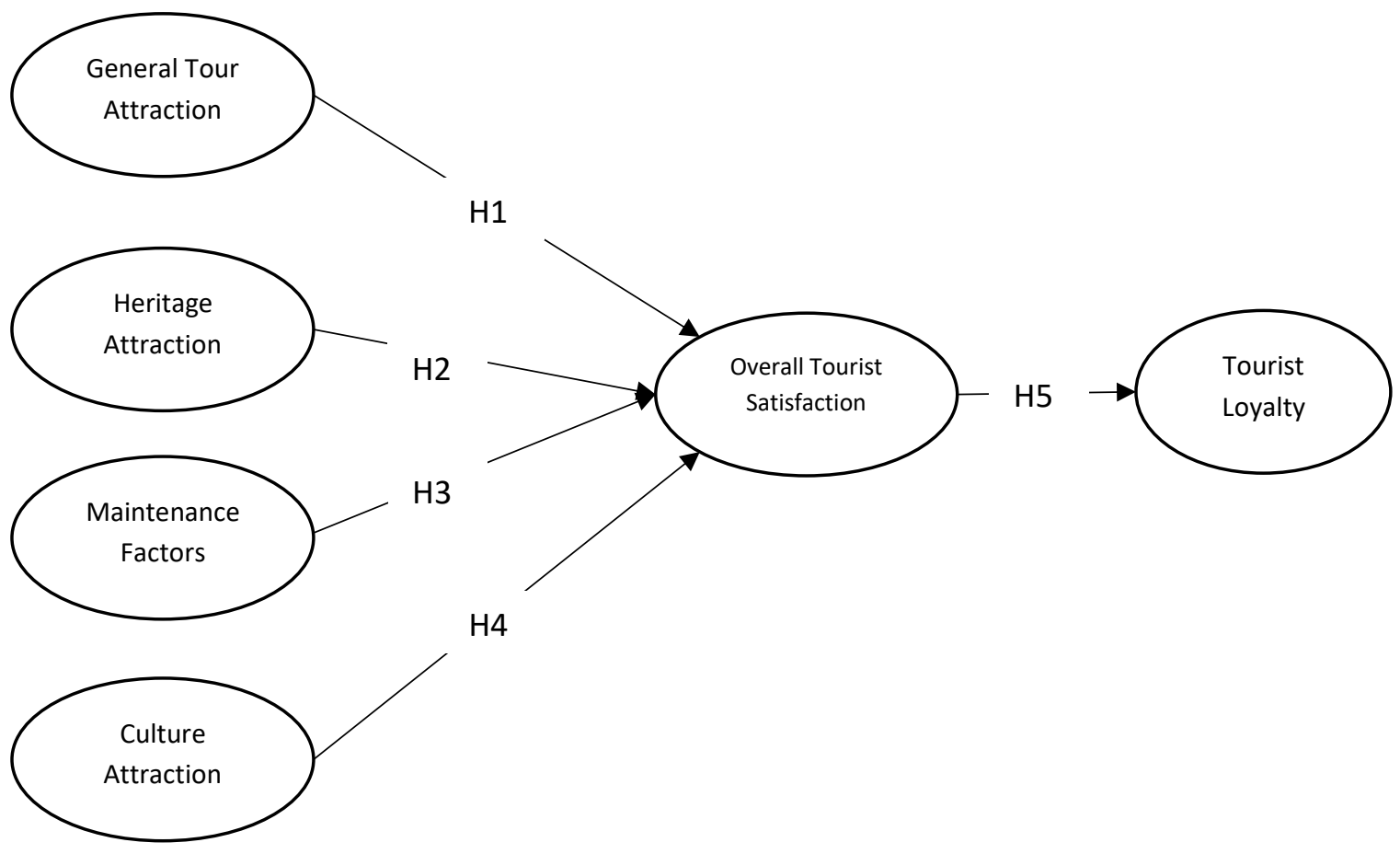

Figure 1. The proposed model

\section{RESEARCH METHOD}

\section{Research approach and instrument}

A quantitative research method was adopted in this study. Partial least squares structural equation modelling (PLS-SEM) was utilised to understand the role of the attributes of cultural destinations, overall tourist satisfaction and loyalty. A self-administered questionnaire was employed for this study. The first part of the questionnaire deals with the measurement of these cultural attributes under 23 headings (Huh \& Uysal, 2004). In this section, four headings relate to overall tourist satisfaction (Oliver, 1980) and three to tourist loyalty (Zhang et al., 2014). All headings in this section were measured by the 5-point Likert scale, where 1 equals strongly disagreed and 5 is strongly agree. The second part includes demographic information about the participant, such as age, gender, education, and previous visits to Istanbul. The research instrument was 
reviewed and revised by four tourism academics before the data was collected.

\section{Sampling and surveying}

Data was gathered from tourists visiting Istanbul through convenience sampling between March 10 and 16, 2019. This is an economical sampling method that allows for swift data collection. A self-administered questionnaire was conducted with tourists in the departure terminal of the airport. First, they were asked whether they had visited and experienced the cultural attractions of Istanbul. They were then asked to participate in the survey questionnaire. The questionnaires were distributed to groups or individual tourists. In all, 450 questionnaires were distributed and collected. However, of this number, 411 were suitable $(95 \%$ confidence and at least 5\%) for data analysis. Cochran's formula (Parvin et al., 2020) state that 384 samples are sufficient for huge or large populations (approximately 15 million tourists arrived in Istanbul in 2019).

\section{Common-method bias}

Since the data was collected via a questionnaire, a bias can occur during the research process. Respondents were first asked to join in the research freely and willingly. This was done to lessen the social desirability bias of the responses (Podsakoff et al., 2003). This study then evaluated the likelihood of common method variance utilising Harman's one-factor test (Fuller et al., 2016). According to this test, the common factor explains $31 \%$ of the variance in the model. Finally, a full collinearity assessment was used to assess common method bias, and variance inflation factor (VIF) values were evaluated. According to this approach, VIF values are expected to equal 3.3 or lower (Kock, 2015). In this research, all values ranged between 1.409 and 3.271, indicating acceptable.

\section{Data analysis}

The data was investigated by utilising the statistical software SPSS 24.0 and Smart-PLS. An exploratory factor analysis was tested by utilising SPSS 24.0, and measurement and structural models were conducted using Smart-PLS 3 to assess the link between constructs recommended in the research model. 


\section{RESULTS AND FINDINGS}

\section{Demographic profile assessment}

Table 1 illustrates the participants' demographic information. There were more male $(57.7 \%)$ than female participants $(42.1 \%)$, whereas only $1.5 \%$ of the respondents were aged 65 years or older. Respondents between the ages of 25 and 44 years $(60.3 \%)$ predominated the sample. Regarding levels of education, $33.1 \%$ of the participants had a bachelor's degree, while $28 \%$ held a master's qualification. Most of those surveyed were single (58.6\%), with $41.1 \%$ married. The majority of the respondents had visited the destination independently $(83.2 \%)$. The results also showed that $52.3 \%$ of the respondents were first-time visitors.

Table 1. Sample characteristics

\begin{tabular}{|c|c|c|c|}
\hline Variable & Description & Frequency & $\%$ \\
\hline \multirow{5}{*}{ Age } & $15-24$ & 111 & 27 \\
\hline & $25-44$ & 248 & 60.3 \\
\hline & $45-64$ & 45 & 11 \\
\hline & $65+$ & 6 & 1.5 \\
\hline & Unspecified & 1 & 0.2 \\
\hline \multirow{3}{*}{ Gender } & Female & 173 & 42.1 \\
\hline & Male & 237 & 57.7 \\
\hline & Unspecified & 1 & 0.2 \\
\hline \multirow[t]{3}{*}{ Marital Status } & Single & 241 & 58.6 \\
\hline & Married & 169 & 41.1 \\
\hline & Unspecified & 1 & 0.2 \\
\hline \multirow[t]{7}{*}{ Education } & $\begin{array}{c}\text { Basic Education } \\
\text { (Primary or secondary } \\
\text { school) }\end{array}$ & 18 & 4.4 \\
\hline & High school & 52 & 12.7 \\
\hline & College diploma & 67 & 16.3 \\
\hline & Bachelor's Degree & 136 & 33.1 \\
\hline & Master & 115 & 28 \\
\hline & Ph.D. & 20 & 4.9 \\
\hline & Unspecified & 3 & 0.7 \\
\hline \multirow[t]{3}{*}{ Type of travel } & Independent & 342 & 83.2 \\
\hline & $\begin{array}{c}\text { Organized Package } \\
\text { Tour }\end{array}$ & 68 & 16.5 \\
\hline & Unspecified & 1 & 0.2 \\
\hline \multirow{2}{*}{$\begin{array}{l}\text { Have you been in } \\
\text { Istanbul before? }\end{array}$} & Yes & 215 & 52.3 \\
\hline & No & 196 & 47.7 \\
\hline Total & & 411 & 100 \\
\hline
\end{tabular}

\section{Exploratory Factor Analysis (EFA)}

As illustrated in Table 2, Kaiser-Meyer-Olkin (KMO) measure of sampling adequacy, Bartlett's Test of Sphericity, and $\mathrm{p}$ values are appropriate to 
employ EFA. With EFA, factor loadings should be higher than 0.40 (Stewart et al., 2001). In this study, four items (i.e. theatres, tour packages, food, and arts) of cultural destination attributes that were less than 0.40 were excluded from the analysis. The results of the analysis are shown in Table 2. Additionally, the cumulative percentage of variance (ranged between $5.44 \%$ and $74.605 \%$ ) and Eigenvalue $>1$ (Kaiser's criteria) rule were adopted for the EFA, as shown in Table 2 (Williams et al., 2010). Finally, the values for skewness and kurtosis were proposed as +2 and -2 for normal distribution (George \& Mallery, 2010), thus confirming this study's normality.

\section{Measurement model test}

The item consistency, convergent, and discriminant validity of the scales were examined for a measurement model test. All the outer loadings of items (except 'guides') surpassed the 0.50 threshold (Bagozzi et al., 1991). The items below 0.50 were excluded from the model and only one item was deleted from the process, as presented in Table 2. The convergent and discriminant validity were assessed in the model. Internal consistency was examined by means of convergent validity. Therefore, composite reliability, Cronbach's alpha coefficients, and rho_A were used to ensure internal consistency reliability. As shown in Table 2, all of Cronbach's alpha coefficients, which show the reliability of constructs and reflect how the observed constructs investigate the latent variable, are ranged from 0.688 to 0.878 , so the results indicate adequate reliability for this model (Taber, 2018). Composite reliability is another reliability measure that should be above 0.70 (Chin, 2010), and all values were above 0.85, which was satisfactory for the measurement model. In addition, rho_A was another indicator that should be calculated for a consistent reliability measure of the partial least squares. In this measurement model, the values of rho_A were above the 0.70 thresholds that are seen as acceptable levels (Dijkstra \& Henseler, 2015). Considering all three indicators, it can be concluded that internal consistency reliability was established for this model. Therefore, there was no lack of internal consistency reliability for this study. 
Table 2. Internal consistency results of exploratory factor analysis (EFA), measurement model and reliability of factors

\begin{tabular}{|c|c|c|c|c|c|c|c|c|c|}
\hline & & \multicolumn{4}{|c|}{ EFA } & \multicolumn{4}{|c|}{ Measurement Model } \\
\hline & Construct/item & FL & E & VE (\%) & CA & SFL & rho_A & CR & AVE \\
\hline \multirow{25}{*}{ 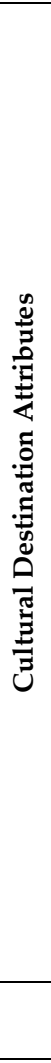 } & General Tour Attraction & & 7.61 & 40.077 & 0.798 & & 0.834 & 0.856 & 0.546 \\
\hline & $\checkmark \quad$ Religious places & 0.625 & & & & 0.762 & & & \\
\hline & $\checkmark$ Souvenirs & 0.814 & & & & 0.846 & & & \\
\hline & $\checkmark \quad$ Theme parks & 0.753 & & & & 0.786 & & & \\
\hline & $\checkmark \quad$ Festivals/events & 0.602 & & & & 0.634 & & & \\
\hline & $\checkmark \quad$ Shopping places & 0.462 & & & & 0.644 & & & \\
\hline & $\checkmark$ Guides & 0.462 & & & & [del] & & & \\
\hline & Maintenance Factors & & 2.01 & 10.580 & 0.812 & & 0.814 & 0.859 & 0.551 \\
\hline & $\checkmark \quad$ Accessibility & 0.702 & & & & 0.792 & & & \\
\hline & $\checkmark \quad$ Indoor facilities & 0.634 & & & & 0.749 & & & \\
\hline & $\checkmark \quad$ Atmosphere/people & 0.669 & & & & 0.755 & & & \\
\hline & $\checkmark \quad$ Information centers & 0.777 & & & & 0.753 & & & \\
\hline & $\checkmark \quad$ Accommodations & 0.640 & & & & 0.656 & & & \\
\hline & Heritage Attraction & & 1.67 & 8.794 & 0.791 & & 0.807 & 0.879 & 0.709 \\
\hline & $\checkmark \quad$ Handcrafts & 0.434 & & & & 0.784 & & & \\
\hline & $\checkmark \quad$ Architecture & 0.780 & & & & 0.870 & & & \\
\hline & $\checkmark \quad$ Traditional scenery & 0.757 & & & & 0.869 & & & \\
\hline & Culture Attraction & & 1.03 & 5.44 & 0.878 & & 0.882 & 0.910 & 0.670 \\
\hline & $\checkmark \quad$ Museums & 0.746 & & & & 0.831 & & & \\
\hline & $\checkmark \quad$ Galleries & 0.738 & & & & 0.783 & & & \\
\hline & $\checkmark \quad$ Culture villages & 0.689 & & & & 0.811 & & & \\
\hline & $\checkmark \quad$ Historic building & 0.576 & & & & 0.855 & & & \\
\hline & $\checkmark \quad$ Monuments & 0.532 & & & & 0.812 & & & \\
\hline & & Bartlett' & $\begin{array}{r}\mathrm{Kl} \\
\text { st of } \mathrm{st}\end{array}$ & $\begin{array}{l}0.886 \\
\text { icity; } 90\end{array}$ & $4 ; \mathrm{p}<0$. & & & & \\
\hline & $\begin{array}{l}\text { Overall Tourist } \\
\text { Satisfaction }\end{array}$ & & 2.984 & 74.605 & 0.877 & & 0.884 & 0.920 & 0.741 \\
\hline \multirow{4}{*}{ 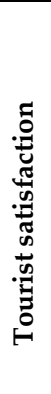 } & $\begin{array}{l}\checkmark \text { Overall I am satisfied } \\
\text { in Istanbul. }\end{array}$ & 0.858 & & & & 0.853 & & & \\
\hline & $\begin{array}{l}\text { I believe I received } \\
\text { what was promised } \\
\text { during my trip. }\end{array}$ & 0.881 & & & & 0.872 & & & \\
\hline & $\begin{array}{l}\checkmark \quad \text { My visit to Istanbul } \\
\text { met my expectations. }\end{array}$ & 0.914 & & & & 0.909 & & & \\
\hline & $\begin{array}{l}\text { My visit to Istanbul } \\
\text { exceeded my } \\
\text { expectations }\end{array}$ & 0.798 & & & & 0.807 & & & \\
\hline
\end{tabular}

KMO: 0.647

Bartlett's Test of sphericity; 291.350; $<<0.000$

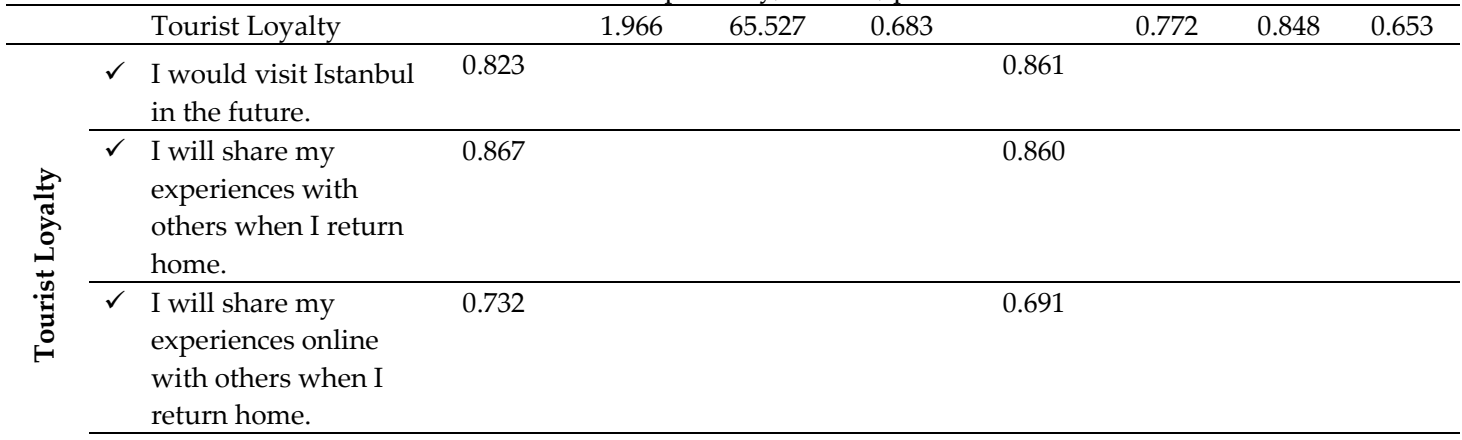

KMO: 0.644

Bartlett's Test of sphericity; 291.051; $\mathrm{p}<0.000$

Remark: FL (Factor Loading); E (Eigenvalue); VE (Variance Explained); CA (Cronbach Alpha); SFL (Standardized factor loadings); CR (Composite Reliability); AVE (Average of variance extracted); [del]: Deleted item. 
Convergent validity was calculated with average variance extracted (AVE), which should have values above 0.50. As shown in Table 2, AVE scores ranged between 0.546 and 0.709 . These values, therefore, confirm convergent validity. Discriminant validity was established based on the Fornell-Larcker criterion (Table 3) and HTMT (Table 4) ratio. This method highlights the distinction of constructs from one another (Hair et al., 2016). The square root of AVE for each of the latent dimensions should be higher than the correlations of any other latent dimensions, in accordance with the Fornell-Larcker criterion (Chin, 2010). This criterion was adopted for this research. Additionally, the Heterotrait-Monotrait ratio of correlation (HTMT) was proposed to assess the discriminant validity, and all values of this approach should be below 0.9 (Henseler et al., 2014). As shown in Table 4, all scores are below 0.9. In summary, it can be inferred that discriminant validity is well established for this measurement model.

Table 3. Discriminant validity (Fornell-Larcker criterion)

\begin{tabular}{|c|c|c|c|c|c|c|}
\hline Constructs & 1 & 2 & 3 & 4 & 5 & 6 \\
\hline Culture Attraction (1) & 0.819 & & & & & \\
\hline General Tour Attraction (2) & 0.519 & 0.739 & & & & \\
\hline Heritage Attraction (3) & 0.668 & 0.513 & 0.842 & & & \\
\hline Maintenance Factors (4) & 0.479 & 0.418 & 0.558 & 0.742 & & \\
\hline $\begin{array}{l}\text { Overall Tourist Satisfaction } \\
\text { (5) }\end{array}$ & 0.441 & 0.324 & 0.371 & 0.286 & 0.742 & \\
\hline Tourist Loyalty (6) & 0.327 & 0.286 & 0.290 & 0.289 & 0.286 & 0.808 \\
\hline \multicolumn{7}{|c|}{$\begin{array}{l}\text { 1.**All correlations are significant at the } 0.01 \text { level }(\mathrm{p}<0.001) \text {. } \\
\text { 2.Boldface numbers are the square root of the AVE. }\end{array}$} \\
\hline \multicolumn{7}{|c|}{ Table 4. Heterotrait-Monotrait Ratio } \\
\hline Constructs & 1 & 2 & 3 & 4 & 5 & 6 \\
\hline \multicolumn{7}{|l|}{ Culture Attraction (1) } \\
\hline General Tour Attraction (2) & 0.617 & & & & & \\
\hline Heritage Attraction (3) & 0.794 & 0.646 & & & & \\
\hline Maintenance Factors (4) & 0.586 & 0.560 & 0.646 & & & \\
\hline $\begin{array}{l}\text { Overall Tourist } \\
\text { Satisfaction (5) }\end{array}$ & 0.497 & 0.362 & 0.560 & 0.330 & & \\
\hline Tourist Loyalty (6) & 0.409 & 0.391 & 0.362 & 0.385 & 0.842 & \\
\hline
\end{tabular}

\section{Structural model test}

The structural model of the research was established according to the outputs of the measurement model test. The research findings show that a variance of $21 \%$ is shown for overall tourist satisfaction and $48 \%$ for tourist loyalty. Therefore, the coefficient of determination $\left(\mathrm{R}^{2}\right)$ values for overall tourist satisfaction and tourist loyalty are greater than the 0.20 cut-off proposed by Hair et al. (2016). In addition to the calculation of $\mathrm{R}^{2}$, predictive 
relevance was used to ensure an additional model fit assessment (Geisser, 1975; Hair et al., 2016). This practice shows the competence of the model to forecast the manifest indicators of each latent construct (Rahman et al., 2020). The cross-validated redundancy (Stone-Geisser $Q^{2}$ ) was calculated to investigate the predictive relevance utilising a blindfolding process. Hair et al. (2016) proposed that the $\mathrm{Q}^{2}$ value should be greater than zero. In this research, the $\mathrm{Q}^{2}$ values of overall tourist satisfaction and tourist loyalty were 0.152 and 0.305 , respectively, which indicated a good fit.

Table 5. Path coefficients

\begin{tabular}{lccccc}
\hline \multicolumn{1}{c}{ Independent to dependent } & $\boldsymbol{\beta}$ & SD & t-values & $\mathbf{P}$ & Result \\
\hline H1: General Tour Attraction $\rightarrow$ Overall Tourist Satisfaction & 0.097 & 0.058 & 1.665 & 0.096 & Not Supported \\
\hline H2: Heritage Attraction $\rightarrow$ Overall Tourist Satisfaction & 0.090 & 0.065 & 1.386 & 0.166 & Not Supported \\
\hline H3: Maintenance Factors $\rightarrow$ Overall Tourist Satisfaction & 0.048 & 0.064 & 0.753 & 0.452 & Not Supported \\
\hline H4: Culture Attraction $\rightarrow$ Overall Tourist Satisfaction & 0.307 & 0.064 & 4.783 & 0.000 & Supported \\
\hline H5: Overall Tourist Satisfaction $\rightarrow$ Tourist loyalty & 0.695 & 0.029 & 23.835 & 0.000 & Supported \\
\hline
\end{tabular}

The Bootstrapping method was implemented with 5,000 resamples to examine the structural model for this research (Hair et al., 2011). The confidence intervals of the bootstrapping technique are precise (Mooney \& Duval, 1993). The outputs of the structural model test are demonstrated in Table 5. The path coefficients of cultural destination attributes on overall tourist satisfaction differ. The outcomes of the model showed that the effect of the general tour attraction $(\beta=0.097)$, heritage attraction $(\beta=0.090)$, and maintenance factors $(\beta=0.048)$ among the destination attributes on overall tourist satisfaction were insignificant. In contrast, the impact of the culture attractions on overall tourist satisfaction $(\beta=0.307)$ was significant. Finally, the impact of overall tourist satisfaction on tourist loyalty $(\beta=0.695)$ was also significant at the level of 0.01. In summary, based on the structural model test, $\mathrm{H} 1, \mathrm{H} 2$, and $\mathrm{H} 3$ were rejected, while $\mathrm{H} 4$ and $\mathrm{H} 5$ were supported.

\section{Multi-Group Analysis (MGA)}

The assessment of variations among the two groups, i.e. first time and repeat visitors, was tested through MGA. First, measurement invariance was analysed before the investigation of MGA for both parties and the measurement invariance of composites (MICOM) was seen as appropriate for PLS-SEM (Henseler et al., 2016). Rasoolimanesh et al. (2017, p.10) proposed three three-stage procedures consisting of a) "a configural invariance assessment", (b) "the establishment of compositional invariance assessment", and (c) "an assessment of equal means and variances". In compliance with MICOM, the partial measurement invariance of first time 
and repeat visitors was built to compare and infer the MGA analysis for both groups in the PLS-SEM (Table 6; Henseler et al., 2016).

As shown in Table 7, Henseler's MGA and the permutation test were selected (Henseler et al., 2009; Matthews, 2017). These methods provided significant differences for the variables mentioned above across both groups (Rasoolimanesh et al., 2017). Utilising these two procedures, the results of MGA in the permutation test indicate a significant difference in the impact of overall tourist satisfaction on tourist loyalty for first time and repeat tourists. As a threshold, 0.1 was considered for the significance level, which is common for MGA (Rasoolimanesh et al., 2017). Therefore, the overall tourist satisfaction for repeat visitors was much higher than for first timers. Other relationships show no differences in both methods.

\section{DISCUSSION}

Destination attributes are crucial dynamics for attracting visitors to a destination (Dann, 1977), although the most appropriate attributes for specific destinations is still matter for discussion among tourism scholars. Among these attributes, previous research pinpointed cultural attractions as being the most important in encouraging potential tourists to visit a destination, and they been found to be a key contributing factor for the economy of that destination (McKercher, 2020). Additionally, it is vital that tourists are satisfied with the cultural attractions of a destination to create loyalty through repeat visits.

To understand the satisfaction levels and loyalty of cultural tourists, it is critical to know which attributes play a major role. The results of the structural model demonstrate that general tour attraction, heritage attraction and maintenance factors among the attributes of cultural destinations have not a significant effect on overall tourist satisfaction. These results were not consistent with the outcomes of work by Huh and Uysal (2004) and Huh et al. (2006). In addition, the extant literature concluded that general tour attraction and maintenance factors (Alegre \& Garau, 2010; Biswas et al., 2020; Eusébio \& Vieira, 2013; Johann \& Ghose, 2018; Kozak, 2002; Ozturk \& Gogtas, 2016) and heritage attributes (Ghosh \& Sofique, 2012; Kim et al., 2007; Leask, 2010) impact tourist satisfaction. According to those studies, these attributes can be beneficial when creating overall tourist satisfaction. However, the findings of this study were not consistent with previous research. 
Table 6. Results of Invariance Measurement Testing Using Permutation

\begin{tabular}{|c|c|c|c|c|c|c|c|c|c|c|c|}
\hline \multicolumn{4}{|c|}{ Compositional invariance $($ Correlation $=1$ ) } & \multirow{2}{*}{$\begin{array}{c}\text { Partial } \\
\text { measurement } \\
\text { invariance } \\
\text { established }\end{array}$} & \multicolumn{3}{|c|}{ Equal mean assessment } & \multicolumn{3}{|c|}{ Equal variance assessment } & \multirow{2}{*}{$\begin{array}{c}\text { Full } \\
\text { measuremen } \\
\text { Invariance } \\
\text { established }\end{array}$} \\
\hline Constructs & $\begin{array}{l}\text { Configural } \\
\text { Invariance }\end{array}$ & $\mathrm{C}=1$ & $\begin{array}{c}\text { Confidence } \\
\text { Interval (CIs) }\end{array}$ & & $\begin{array}{c}\text { Differences } \\
\text { (First-Timer/ } \\
\text { Repeater) }\end{array}$ & $\begin{array}{l}\text { Confidence } \\
\text { Interval (CIs) }\end{array}$ & Equal & $\begin{array}{c}\text { Differences } \\
\text { (First-Timer/ } \\
\text { Repeater) }\end{array}$ & $\begin{array}{c}\text { Confidence } \\
\text { Interval (CIs) }\end{array}$ & Equal & \\
\hline $\begin{array}{c}\text { Culture } \\
\text { Attraction }\end{array}$ & Yes & 0.998 & {$[0.994,1.000]$} & Yes & 0.069 & {$[-0.164-0.179]$} & Yes & -0.176 & {$[-0.244,0.240]$} & Yes & Yes \\
\hline $\begin{array}{c}\text { General Tour } \\
\text { Attraction } \\
\end{array}$ & Yes & 0.970 & {$[0.965,1.000]$} & Yes & 0.059 & {$[-0.161,0.158]$} & Yes & -0.003 & {$[-0.174,0.181]$} & Yes & Yes \\
\hline $\begin{array}{c}\text { Heritage } \\
\text { Attraction }\end{array}$ & Yes & 0.998 & {$[0.987,1.000]$} & Yes & 0.160 & {$[-0.159,0.181]$} & Yes & -0.269 & {$[-0.246,0.223]$} & No & No \\
\hline $\begin{array}{l}\text { Maintenance } \\
\text { Factors }\end{array}$ & Yes & 0.966 & {$[0.965,1.000]$} & Yes & 0.015 & {$[-0.169-0.167]$} & Yes & -0.153 & {$[-0.256,0.225]$} & Yes & Yes \\
\hline $\begin{array}{c}\text { Overall Tourist } \\
\text { Satisfaction } \\
\end{array}$ & Yes & 0.999 & {$[0.999,1.000]$} & Yes & -0.023 & {$[-0.160,0.158]$} & Yes & 0.047 & {$[-0.244,0.273]$} & Yes & Yes \\
\hline Tourist Loyalty & Yes & 0.999 & {$[0.995,1.000]$} & Yes & -0.014 & {$[-0.165,0.153]$} & Yes & 0.217 & {$[-0.288,0.323]$} & Yes & Yes \\
\hline
\end{tabular}

Table 7. Estimated structural model: Multi-Group Analysis (PLS-MGA) Path Coefficient Confidence Interval (95\%) Bias Corrected

\begin{tabular}{|c|c|c|c|c|c|c|c|c|}
\hline Relationships & First-time Visitor & Repeat Visitor & First-time Visitor & Repeat Visitor & Path Coefficient Difference & Henseler's MGA & Permutation test & Results \\
\hline $\mathrm{CA} \rightarrow \mathrm{OTS}$ & 0.272 & 0.341 & {$[0.074,0.463]$} & {$[0.186,0.509]$} & -0.069 & 0.592 & 0.278 & No/No \\
\hline GTA $\rightarrow$ OTS & 0.048 & 0.163 & {$[-0.163,0.214]$} & {$[0.022,0.300]$} & -0.115 & 0.332 & 0.178 & $\mathrm{No} / \mathrm{No}$ \\
\hline $\mathrm{HA} \rightarrow \mathrm{OTS}$ & 0.114 & 0.061 & {$[-0.078,0.306]$} & {$[-0.088,0.235]$} & 0.053 & 0.677 & 0.328 & $\mathrm{No} / \mathrm{No}$ \\
\hline $\mathrm{MF} \rightarrow \mathrm{OTS}$ & 0.091 & 0.035 & {$[-0.066,0.215]$} & {$[-0.140,0.189]$} & 0.056 & 0.636 & 0.340 & No/No \\
\hline $\mathrm{OTS} \rightarrow \mathrm{TL}$ & 0.651 & 0.748 & {$[0.540,0.730]$} & {$[0.679,0.811]$} & -0.097 & 0.089 & 0.050 & No/Yes \\
\hline
\end{tabular}

Note: In "Henseler's MGA process, a p value lower than 0.05 or greater than 0.95 shows 5\% level significant differences between two groups" (Rasoolimanesh et al., 2017).; CA: Cultural

Attraction; GTA: General Tour Attraction; HA: Heritage Attraction; MF: Maintenance Factors; OTS: Overall Tourist Satisfaction; TL: Tourist Loyalty 
The cultural attraction of a destination affects overall tourist satisfaction. A study by Huh and Uysal (2004) found that cultural attraction determines the overall satisfaction of tourists with a destination. Specifically, Altunel and Erkut (2015) found that visits to museums, culture villages, historical attractions, galleries, and monuments impact not only the quality of the experience for tourists but also satisfaction with the destination. The study by Huh et al. (2006) indicated that cultural experience determines overall tourist satisfaction. This finding supports previous work conducted at different cultural tourism destinations.

As demonstrated above, most tourism scholars show that tourist satisfaction impacts tourist loyalty (Eusébio \& Vieira, 2013; Gursoy et al., 2014; Lee et al., 2011; McDowall, 2010; Suhartanto et al., 2020). In line with these studies, this study found that overall tourist satisfaction with cultural attributes influences tourist loyalty. Therefore, a visitor who is satisfied from the attractions of a destination is expected to make a return visit. Additionally, loyalty to a destination may also occur following recommendations from other visitors.

\section{CONCLUSION AND IMPLICATIONS}

\section{Contribution}

The overarching aim of this paper was to investigate the influence of cultural destination attributes on overall tourist satisfaction and tourist loyalty. Additionally, this research compared tourist groups according to their frequency of visit, such as first time and repeat visitors. This study is the first to attempt an examination of these roles for Istanbul. Therefore, this research will contribute to the relevant literature on visit frequency. The literature does not include holistic research on cultural attributes, satisfaction and loyalty. Therefore, the model tested in this study will be a useful contribution to the tourism literature.

\section{Theoretical implications}

This research has some important implications that may be helpful in future research. First, this study expanded the scope of destination attributes and focused specifically on cultural attributes. Therefore, the results of this study reinforce the message contained in the marketing literature for tourist destinations. For example, this study has shown that cultural attractions have a major impact on tourist satisfaction, and this was supported by extant research. However, other attributes, such as general tour attraction, 
maintenance factors and heritage attractions do not affect overall tourist satisfaction. Therefore, these findings will assist researchers in formulating models for further research.

Second, this research has some major implications for future studies of visit frequency. This study aimed to compare the differences between path coefficients of first time and repeat visitors. MGA was employed to ascertain the differences between both groups. According to this analysis, it was concluded that only one difference in the impact of overall tourist satisfaction on tourist loyalty occurred among the groups, in accordance with the permutation test. This finding using MGA will aid scholars when they compare their research results.

\section{Managerial implications}

This research also provides a broad outline for those managing and marketing tourist destinations of which attributes are crucial for tourist satisfaction and the future behavioural intentions of the visitor. Cultural attractions are key attributes for destinations in terms of encouraging tourists to visit. To increase the satisfaction of international travellers visiting Istanbul, and tourist loyalty to it as a cultural destination, this research suggests that more cultural attractions should be provided, including historic buildings, monuments, culture villages, galleries, and museums. Marketing teams can then use these attractions when promoting the destination on various social media or promotional platforms. Fundamentally, all cultural attributes of a destination are critical and necessary to ensure tourist satisfaction and to create tourist loyalty. Based on the findings of this study, this segment of the tourism market should be targeted though the promotion of cultural attractions. Those involved in the tourism sector should make themselves aware of the specific attractions that motivate first-time visitors to become repeat visitors and they should focus on preserving and improving these attributes.

\section{Limitations and future research lines}

This research was conducted in Istanbul, so the findings are specific to this destination. Therefore, similar research could be conducted in other tourism settings. The literature shows that the influence of destination attributes on the image of a destination (Chahal \& Devi, 2015), and on the motivation of visitors to travel to these destinations (Levitt et al., 2017), is well known. Additionally, future studies can illuminate the role of cultural destination attributes on the variables referred to in this study, which adopted a 
quantitative methodological approach. Further research could include qualitative interviews with tourists visiting cultural destinations to determine the main cultural attributes of those destinations. This research was conducted prior to the outbreak of COVID-19. However, some potential future tourists visited several cultural and heritage sites through virtual reality technology during the pandemic (Ats1z, 2021). Therefore, this study suggests that further research is conducted on the satisfaction levels of these virtual visitors to cultural attractions and how this experience may impact their future intentions to physically visit the city. Finally, cultural tourism destinations are essential to maintain the existing tourism environment. As such, an examination of the cultural attributes that determine tourist satisfaction and loyalty is strongly recommended.

\section{ACKNOWLEDGMENT}

This paper is a part of first author's doctoral dissertation thesis entitled "Tourists' length of stay in cultural destination."

\section{REFERENCES}

Ajzen, I. (2005). Attitude, personality, and behavior (2nd ed.). Open University Press.

Akova, O., \& Atsız, O. (2019). Sociocultural impacts of tourism development on heritage sites. In D. Gürsoy, \& R. Nunkoo (Eds.), The Routledge handbook of tourism impacts (pp. 252-264). London: Routledge.

Albayrak, T., \& Caber, M. (2013). The symmetric and asymmetric influences of destination attributes on overall visitor satisfaction. Current Issues in Tourism, 16(2), 149-166. https://doi.org/10.1080/13683500.2012.682978

Alegre, J., \& Garau, J. (2010). Tourist Satisfaction and Dissatisfaction. Annals of Tourism Research, 37(1), 52-73. https://doi.org/10.1016/j.annals.2009.07.001

Almeida-Santana, A., \& Moreno-Gil, S. (2018). Understanding tourism loyalty: Horizontal vs. destination loyalty. Tourism Management, 65, 245-255. https://doi.org/10.1016/j.tourman.2017.10.011

Altunel, M. C., \& Erkut, B. (2015). Cultural tourism in Istanbul: The mediation effect of tourist experience and satisfaction on the relationship between involvement and recommendation intention. Journal of Destination Marketing and Management, 4(4), 213-221. https://doi.org/10.1016/j.jdmm.2015.06.003

Atsız, O. (2021). Virtual reality technology and physical distancing: A review on limiting human interaction in tourism. Journal of Multidisciplinary Academic Tourism, 6(1), 27-35. https://doi.org/10.31822/jomat.834448

Atsız, O., Leoni, V., \& Akova, O. (2020). Determinants of tourists' length of stay in cultural destination: one-night vs longer stays. Journal of Hospitality and Tourism Insights. https://doi.org/10.1108/jhti-07-2020-0126

Babolian Hendijani, R. (2016). Effect of food experience on tourist satisfaction: the case of Indonesia. International Journal of Culture, Tourism, and Hospitality Research, 10(3), 272-282. https://doi.org/10.1108/IJCTHR-04-2015-0030 
Bagozzi, R. P., Yi, Y., \& Phillips, L. W. (1991). Assessing Construct Validity in Organizational Research. Administrative Science Quarterly, 36(3). https://doi.org/10.2307/2393203

Baloglu, S., Pekcan, A., Chen, S. L., \& Santos, J. (2004). The relationship between destination performance, overall satisfaction, and behavioral intention for distinct segments. Journal of Quality Assurance in Hospitality and Tourism, 4(3-4), 149-165. https://doi.org/10.1300/J162v04n03_10

Biodun, A. B., Din, A. K. H., \& Abdullateef, A. O. (2013). The relationship between tourist expectation, perceived quality and satisfaction with tourism products. International Business Management, 7(3), 158-164. https://doi.org/10.3923/ibm.2013.158.164

Biswas, C., Deb, S. K., Hasan, A. A.-T., \& Khandakar, M. S. A. (2020). Mediating effect of tourists' emotional involvement on the relationship between destination attributes and tourist satisfaction. Journal of Hospitality and Tourism Insights, ahead-of-p. https://doi.org/10.1108/jhti-05-2020-0075

Buhalis, D. (2000). Marketing the competitive destination of the future. Tourism Management, 21(1), 97-116. https://doi.org/10.1016/S0261-5177(99)00095-3

Cetin, G. (2020). Experience vs quality: predicting satisfaction and loyalty in services. Service Industries Journal, 40(15-16), 1167-1182. https://doi.org/10.1080/02642069.2020.1807005

Chahal, H., \& Devi, A. (2015). Destination Attributes and Destination Image Relationship in Volatile Tourist Destination: Role of Perceived Risk. Metamorphosis: A Journal of Management Research, 14(2), 1-19. https://doi.org/10.1177/0972622520150203

Chen, C.-F., \& Myagmarsuren, O. (2010). Exploring Relationships between Mongolian Destination Brand Equity, Satisfaction and Destination Loyalty. Tourism Economics, 16(4), 981-994. https://doi.org/10.5367/te.2010.0004

Chi, C. G. Q. (2012). An examination of destination loyalty: Differences between first-time and repeat visitors. Journal of Hospitality and Tourism Research, 36(1). https://doi.org/10.1177/1096348010382235

Chi, C. G. Q., \& Qu, H. (2008). Examining the structural relationships of destination image, tourist satisfaction and destination loyalty: An integrated approach. Tourism Management, 29(4), 624-636. https://doi.org/10.1016/j.tourman.2007.06.007

Chin, W. W. (2010). How to Write Up and Report PLS Analyses. In V. Vinzi, W. Chin, J. Henseler, \& H. Wang (Eds.), Handbook of Partial Least Squares: Concepts, methods and application (pp. 645-689). Springer. https://doi.org/10.1007/978-3-540-32827-8_29

Chon, K.-S., \& Olsen, M. D. (1991). Functional and symbolic congruity approaches to consumer satisfaction/dissatisfaction in tourism. Journal of the International Academy of Hospitality Research, 3, 2-22.

Cong, L. C. (2016). A formative model of the relationship between destination quality, tourist satisfaction and intentional loyalty: An empirical test in Vietnam. Journal of Hospitality and Tourism Management, 26, 50-62

Dann, G. M. S. (1977). Anomie, ego-enhancement and tourism. Annals of Tourism Research, 4(4). https://doi.org/10.1016/0160-7383(77)90037-8

del Bosque, I. R., \& San Martín, H. (2008). Tourist satisfaction a cognitive-affective model. Annals of Tourism Research, 35(2), 551-573. https://doi.org/10.1016/j.annals.2008.02.006

Dijkstra, T. K., \& Henseler, J. (2015). Consistent partial least squares path modeling. MIS Quarterly: Management Information Systems, 39(2), 297-316. https://doi.org/10.25300/MISQ/2015/39.2.02 
Eusébio, C., \& Vieira, A. L. (2013). Destination Attributes' Evaluation, Satisfaction and Behavioural Intentions: A Structural Modelling Approach. International Journal of Tourism Research, 15(1), 66-80. https://doi.org/10.1002/jtr.877

Fuller, C. M., Simmering, M. J., Atinc, G., Atinc, Y., \& Babin, B. J. (2016). Common methods variance detection in business research. Journal of Business Research, 69(8). https://doi.org/10.1016/j.jbusres.2015.12.008

Geisser, S. (1975). The predictive sample reuse method with applications. Journal of the American Statistical Association, 70(350). https://doi.org/10.1080/01621459.1975.10479865

George, D., \& Mallery, P. (2010). SPSS for Windows Step by Step: A Simple Guide and Reference Fourth Edition. Boston: Pearson Education, Inc.

Gezici, F., \& Kerimoglu, E. (2010). Culture, tourism and regeneration process in Istanbul. International Journal of Culture, Tourism and Hospitality Research, 4(3), 252-265. https://doi.org/10.1108/17506181011067637

Ghosh, P., \& Sofique, M. A. (2012). Tourist Satisfaction at Cultural Heritage Destinations: An Empirical Study of West Bengal, India. Asian Journal of Multidimensional Research, 1(6), 55-68.

Gursoy, D., Akova, O., \& Atsız, O. (2021). Understanding the heritage experience: a content analysis of online reviews of World Heritage Sites in Istanbul. Journal of Tourism and Cultural Change, 1-24. https://doi.org/10.1080/14766825.2021.1937193

Gursoy, D., Chen, J. S., \& Chi, C. G. (2014). Theoretical examination of destination loyalty formation. International Journal of Contemporary Hospitality Management, 26(5), 809827. https://doi.org/10.1108/IJCHM-12-2013-0539

Hair, J., Hult, G., Ringle, C., \& Sarstedt, M. (2016). A primer on partial least squares structural equation modeling (PLS-SEM). Sage.

Hair, J. F., Ringle, C. M., \& Sarstedt, M. (2011). PLS-SEM: Indeed a silver bullet. Journal of Marketing theory and Practice, 19(2), 139-152.

Henseler, J., Ringle, C. M., \& Sarstedt, M. (2014). A new criterion for assessing discriminant validity in variance-based structural equation modeling. Journal of the Academy of Marketing Science, 43(1). https://doi.org/10.1007/s11747-014-0403-8

Henseler, J., Ringle, C. M., \& Sarstedt, M. (2016). Testing measurement invariance of composites using partial least squares. International Marketing Review, 33(3), 405431. https://doi.org/10.1108/IMR-09-2014-0304

Henseler, J., Ringle, C. M., \& Sinkovics, R. R. (2009). The use of partial least squares path modeling in international marketing. Advances in International Marketing, 20, 277319. https://doi.org/10.1108/S1474-7979(2009)0000020014

Huh, J., \& Uysal, M. (2004). Satisfaction with cultural/heritage sites. Journal of Quality Assurance in Hospitality and Tourism, 4(3-4), 177-194. https://doi.org/10.1300/J162v04n03_12

Huh, J., Uysal, M., \& McCleary, K. (2006). Cultural/heritage destinations: Tourist satisfaction and market segmentation. Journal of Hospitality and Leisure Marketing, 14(3), 81-99. https://doi.org/10.1300/J150v14n03_07

Hui, T. K., Wan, D., \& Ho, A. (2007). Tourists' satisfaction, recommendation and revisiting $\begin{array}{llll}\text { Singapore. Tourism } & \text { 28(4), 965-975. }\end{array}$ https://doi.org/10.1016/j.tourman.2006.08.008

İstanbul Provincial Directorate of Culture and Tourism. (2020). Istanbul Turizm İstatistikleri. Johann, M., \& Ghose, S. (2018). Measuring tourist satisfaction with destination attributes. Journal of Management and Financial Sciences, 34, 9-22. 
Jumanazarov, S., Kamilov, A., \& Kiatkawsin, K. (2020). Impact of Samarkand's Destination Attributes on International Tourists' Revisit and Word-of-Mouth Intention. Sustainability, 12(12), 5154. https://doi.org/10.3390/su12125154

Kim, H., Cheng, C. K., \& O'Leary, J. T. (2007). Understanding participation patterns and trends in tourism cultural attractions. Tourism Management, 28(5), 1366-1371. https://doi.org/10.1016/j.tourman.2006.09.023

Kim, J. H. (2014). The antecedents of memorable tourism experiences: The development of a scale to measure the destination attributes associated with memorable experiences. Tourism Management, 44, 34-45. https://doi.org/10.1016/j.tourman.2014.02.007

Kock, N. (2015). Common method bias in PLS-SEM: A full collinearity assessment approach. International Journal of E-Collaboration, 11(4), 1-10. https://doi.org/10.4018/ijec.2015100101

Kozak, M. (2002). Measuring tourist satisfaction with multiple destination attributes. Tourism Analysis, 7(3-4), 229-240. https://doi.org/10.3727/108354203108750076

Kwanisai, G., \& Vengesayi, S. (2016). Destination attributes and overall destination satisfaction in Zimbabwe. Tourism Analysis, 21(1), 17-28. https://doi.org/10.3727/108354216X14537459508775

Leask, A. (2010). Progress in visitor attraction research: Towards more effective management. Tourism Management, 31(2), 155-166. https://doi.org/10.1016/j.tourman.2009.09.004

Lee, S., Jeon, S., \& Kim, D. (2011). The impact of tour quality and tourist satisfaction on tourist loyalty: The case of Chinese tourists in Korea. Tourism Management, 32(5), 1115-1124. https://doi.org/10.1016/j.tourman.2010.09.016

Levitt, J. A., Zhang, P., DiPietro, R. B., \& Meng, F. (2017). Food tourist segmentation: Attitude, behavioral intentions and travel planning behavior based on food involvement and motivation. International Journal of Hospitality and Tourism Administration, 20(2), 129-155. https://doi.org/10.1080/15256480.2017.1359731

Lew, A. A. (1987). A framework of tourist attraction research. Annals of Tourism Research, 14(4), 553-575. https://doi.org/10.1016/0160-7383(87)90071-5

Matthews, L. (2017). Applying multigroup analysis in PLS-SEM: A step-by-step process. In H. Latan \& R. Noonan (Eds.), Partial Least Squares Path Modeling (pp. 219-243). Springer. https://doi.org/10.1007/978-3-319-64069-3_10

McDowall, S. (2010). International Tourist Satisfaction and Destination Loyalty: Bangkok, Thailand. Asia Pacific Journal of Tourism Research, 15(1), 21-42. https://doi.org/10.1080/10941660903510040

McKercher, B. (2020). Cultural tourism market: a perspective paper. Tourism Review, 75(1), 126-129. https://doi.org/10.1108/TR-03-2019-0096

Meng, F., Tepanon, Y., \& Uysal, M. (2008). Measuring tourist satisfaction by attribute and motivation: The case of a nature-based resort. Journal of Vacation Marketing, 14(1), 41-56. https://doi.org/10.1177/1356766707084218

Moniz, A. I. (2012). A Dynamic Analysis of Repeat Visitors. Tourism Economics, 18(3), 505517. https://doi.org/10.5367/te.2012.0129

Moon, H., \& Han, H. (2018). Destination attributes influencing Chinese travelers' perceptions of experience quality and intentions for island tourism: A case of Jeju Island. Tourism Management Perspectives, 28, 71-82. https://doi.org/10.1016/j.tmp.2018.08.002

Mooney, C. Z., \& Duval, R. (1993). Bootstrapping: A Nonparametric Approach to Statistical Inference. Sage. 
Oliver, R. L. (1980). A Cognitive Model of the Antecedents and Consequences of Satisfaction Decisions. Journal of Marketing Research, 17(4). https://doi.org/10.1177/002224378001700405

Ozturk, U. A., \& Gogtas, H. (2016). Destination attributes, satisfaction, and the cruise visitor's intent to revisit and recommend. Tourism Geographies, 18(2), 194-212. https://doi.org/10.1080/14616688.2015.1124446

Parvin, M., Razavian, M. T., \& Tavakolinia, J. (2020). Importance of urban tourism planning in Tehran with economic approach. Journal of Tourism Hospitality Research, 7(2), 95-110.

Pizam, A., Neumann, Y., \& Reichel, A. (1978). Dimentions of tourist satisfaction with a destination area. Annals of Tourism Research, 5(3), 314-322. https://doi.org/10.1016/0160-7383(78)90115-9

Podsakoff, P. M., MacKenzie, S. B., Lee, J. Y., \& Podsakoff, N. P. (2003). Common Method Biases in Behavioral Research: A Critical Review of the Literature and Recommended Remedies. Journal of Applied Psychology, 88(5), 879-903. https://doi.org/10.1037/0021-9010.88.5.879

Prentice, R. (1993). Tourism and Heritage Attractions. Routledge.

Rahman, M., Moghavvemi, S., Thirumoorthi, T., \& Rahman, M. K. (2020). The impact of tourists' perceptions on halal tourism destination: a structural model analysis. Tourism Review, 75(3), 575-594. https://doi.org/10.1108/TR-05-2019-0182

Rasoolimanesh, S. M., Roldán, J. L., Jaafar, M., \& Ramayah, T. (2017). Factors Influencing Residents' Perceptions toward Tourism Development: Differences across Rural and Urban World Heritage Sites. Journal of Travel Research, 56(6), 760-775. https://doi.org/10.1177/0047287516662354

Reichheld, F. F. (2003). The one number you need to grow. Harvard Business Review, 81(12), 46.

Reisinger, Y., Mavondo, F. T., \& Crotts, J. C. (2009). The importance of destination attributes: Western and Asian visitors. Anatolia, 20(1), 236-253. https://doi.org/10.1080/13032917.2009.10518907

Richards, G. (2018). Cultural tourism: A review of recent research and trends. Journal of Hospitality and Tourism Management, 36, 12-21. https://doi.org/10.1016/j.jhtm.2018.03.005

Schofield, P., Coromina, L., Camprubi, R., \& Kim, S. (2020). An analysis of first-time and repeat-visitor destination images through the prism of the three-factor theory of consumer satisfaction. Journal of Destination Marketing and Management, 17, 100463. https://doi.org/10.1016/j.jdmm.2020.100463

Sirakaya, E., McLellan, R. W., \& Uysal, M. (1996). Modeling vacation destination decisions: A behavioral approach. Journal of Travel and Tourism Marketing, 5(1-2), 57-75. https://doi.org/10.1300/J073v05n01_05

Stewart, D., Barnes, J., Cote, J., Cudeck, R., \& Malthouse, E. (2001). Factor Analysis. Journal of Consumer Psychology, 10(1-2), 75-82. https://doi.org/10.1207/S15327663JCP1001\&2_07

Suhartanto, D. (2018). Tourist satisfaction with souvenir shopping: evidence from Indonesian domestic tourists. Current Issues in Tourism, 21(6), 663-679. https://doi.org/10.1080/13683500.2016.1265487

Suhartanto, D., Brien, A., Primiana, I., Wibisono, N., \& Triyuni, N. N. (2020). Tourist loyalty in creative tourism: the role of experience quality, value, satisfaction, and motivation. Current Issues in Tourism, 23(7), 867-879. https://doi.org/10.1080/13683500.2019.1568400 
Taber, K. S. (2018). The Use of Cronbach's Alpha When Developing and Reporting Research Instruments in Science Education. Research in Science Education, 48(6), 1273-1296. https://doi.org/10.1007/s11165-016-9602-2

Turkish Statistical Institute (TUIK). (2020). Statistical indicators: Province indicators. Turkish Statistical Institute. https://biruni.tuik.gov.tr/ilgosterge/?locale=tr

UNESCO. (2020). Historic Areas of Istanbul. https://whc.unesco.org/en/list/356/

Vareiro, L., Ribeiro, J. C., \& Remoaldo, P. C. (2019). What influences a tourist to return to a cultural destination? International Journal of Tourism Research, 21(2), 280-290. https://doi.org/10.1002/JTR.2260

Williams, B., Onsman, A., \& Brown, T. (2010). Exploratory factor analysis: A five-step guide for novices. Journal of Emergency Primary Health Care, 8(3), 1-13. https://doi.org/10.33151/ajp.8.3.93

Yoon, Y., \& Uysal, M. (2005). An examination of the effects of motivation and satisfaction on destination loyalty: A structural model. Tourism Management, 26(1), 45-56. https://doi.org/10.1016/j.tourman.2003.08.016

Zhang, H., Fu, X., Cai, L. A., \& Lu, L. (2014). Destination image and tourist loyalty: A metaanalysis. Tourism Management, 40, 213-223. https://doi.org/10.1016/j.tourman.2013.06.006 